\title{
NÍSIA FLORESTA: O CONHECIMENTO COMO FONTE DE EMANCIPAÇÃO E A FORMAÇÃO DA CIDADANIA FEMININA ${ }^{1}$
}

\author{
Dra. Cleide Rita Silvério de Almeida ${ }^{2}$ \\ Universidade Nove de Julho - UNINOVE, São Paulo, Brasil \\ calmeida@uninove.br \\ Dra. Elaine Teresinha Dal Mas Dias ${ }^{3}$ \\ Universidade Nove de Julho - UNINOVE, São Paulo, Brasil \\ elaine.mas@uninove.br
}

Recepción: 26/07/2009

Evaluación: 29/09/2009

Aceptación: 08/10/2009

Articulo de Reflexión

\section{RESUMO}

Este artigo apresenta vida e obra de Nísia Floresta, a influência de sua prática educativa no século XIX e a repercussão de suas proposições na atualidade. Resgatar sua memória e divulgá la é uma tarefa política, pois traz à luz uma identidade caleisdoscópica que interferiu, educacionalmente, em sua época. Consciência antecipadora delineou a emancipação feminina pela via do conhecimento e denunciou as injustiças impostas às mulheres. Educada e de grande erudição, captou os debates tecidos em seu tempo e articulou diálogos entre as idéias européias e o contexto brasileiro. Sua verve crítica permitiu analisar o mundo, não como algo dado, mas como um lugar de desvelamentos, analisar a educação e indignar-se com ela, ver o lugar destinado à mulher e escrever sobre como seria possível transformá-lo.

Palabras clave: Educação; Conhecimento; Emancipação; Inclusão.

\footnotetext{
1 Artículo presentado en el Simposio de Educadores Latinoamericanos, en el marco del VII Congreso Internacional de la Sociedad de Historia de la Universidad Latinoamericana, Sao Paulo (Brasil), agosto de 2009.

2 Doutora em Educação pela Universidade de São Paulo - USP, São Paulo, Brasil, 1997. Universidade Nove de Julho - UNINOVE, São Paulo, Brasil.

3 Doutora em Psicologia pela Universidade de São Paulo - USP, São Paulo, Brasil, 2001.

Universidade Nove de Julho - UNINOVE, São Paulo, Brasil.
} 


\title{
NÍSIA FLORESTA: KNOWLEDGE AS A SOURCE OF EMANCIPATION IN THE FEMALE CITIZENSHIP TRAINING
}

\author{
Dra. Cleide Rita Silvério de Almeida \\ Universidade Nove de Julho - UNINOVE, São Paulo, Brasil. \\ calmeida@uninove.br \\ Dra. Elaine Teresinha Dal Mas Dias \\ Universidade Nove de Julho - UNINOVE, São Paulo, Brasil \\ elaine.mas@uninove.br
}

\begin{abstract}
This article presents Nísia FLoresta's life and work, her influence on the educational practice in the nineteenth century and the impact of her proposals today. She represents the female emancipation through knowledge and denounced the injustices imposed on women at that time. Her debates articulated dialogue between European ideas and the Brazilian context. Her critical verve allowed to examine the world, not as something given but as a place of disclosures, review the education practice and resent about it, showing the place assigned to women, and consequently she stated her viewpoint about how that would be possible to be transformed.
\end{abstract}

Key words: Education, Knowledge, Emancipation, Inclusion. 


\section{INTRODUÇÃO}

Apresentar Nísia Floresta Brasileira Augusta ou Dionísia Gonçalves Pinto ou, simplesmente, Nísia Floresta significa lembrar a importância e o significado de uma mulher que se destacou pela consciência antecipadora, influenciou a prática educacional no final do século XIX, impulsionou a emancipação feminina pela via do conhecimento e denunciou as injustiças a que eram submetidos escravos e índios em território brasileiro. Iluminar sua memória e sua obra, seus projetos e suas ações são tarefas de cunho político, pois evidencia uma personalidade que influenciou sua época e construiu uma identidade caleidoscópica no desempenho das funções de filha, mãe, esposa, escritora, educadora, poetisa, tradutora e jornalista, ao longo de 75 anos de existência. Viveu nos estados do Rio Grande do Norte, Pernambuco, Rio Grande do Sul e Rio de Janeiro, e visitou Portugal, Itália, Alemanha, Grécia, Inglaterra e França, onde passou a maior parte de sua vida. O deslocamento por uma pluralidade de lugares ajudou a construir uma pessoa aberta e arrojada que rompeu os limites do lugar social e educacional destinado à mulher, ultrapassou o anonimato, desenvolveu uma ampla cultura, expôs suas idéias e clamou por respeito. Educada e de grande erudição captou os debates tecidos em seu tempo, mostrando sua capacidade de articular e estabelecer diálogos entre as idéias européias e o contexto brasileiro, tanto em sua produção literária quanto em sua vida. Expressou sua forma de pensar e sua experiência em uma obra consistente traduzida e publicada em diversas línguas. Movimentou seu nome e seus pseudônimos em uma complexa trama de relações sociais, históricas, familiares e afetivas, que revelavam uma individualidade marcante envolvida por uma multiplicidade de eus.

Para entendermos o sentido das denúncias e reivindicações de Nísia Floresta é importante relembrar as condições em que viviam as mulheres no século XIX: fundamentalmente num contexto de reclusão, em que a casa era o espaço de vivência e convivência. Eram educadas para o casamento, a maternidade e o respeito e aquiescência aos pais e maridos. As janelas das residências abriam perspectivas ao mundo exterior, desde que usadas com discrição, evitando-se grande exposição. Nessa cultura de submissão, as uniões matrimoniais eram acordadas entre os pais dos futuros noivos e, muitas vezes, baseadas em critérios de conveniência.

Ao caminhar a contrapelo Nísia Floresta deu voz aos vencidos e ao narrar suas experiências, idéias e viagens, deixou seu registro "como à tigela de barro a marca das mãos do oleiro." $" \mathrm{Na}$ tarefa de apresentar o percurso da educadora, optamos por apresentar na primeira parte, o

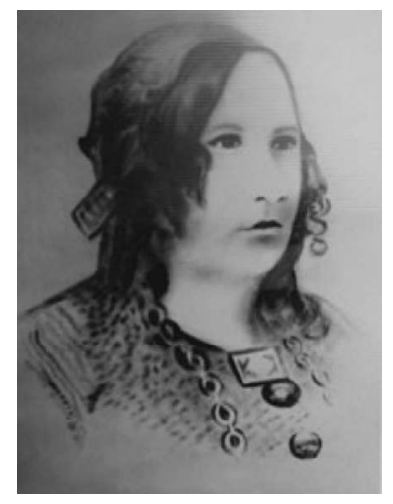

Nísia Floresta Contexto de Inserção, mostrando onde e de que modo viveu a autora, detalhando os movimentos sociais e políticos nacionais travados à época; na segunda, em a História de uma brasileira, descrevemos sua vida e obra; e na terceira, retratamos seus Sonhos educacionais.

4 BENJAMIN, Walter. (1983): O narrador: Observações sobre a obra de Nikolai Leskow, in Coleção: Os Pensadores. Textos escolhidos: Benjamin, Horkheimer, Adorno, Habermas, 2 ed, pp. 62-63. São Paulo: Abril. (Trabalho original publicado em 1936). 


\section{Contexto de Inserção}

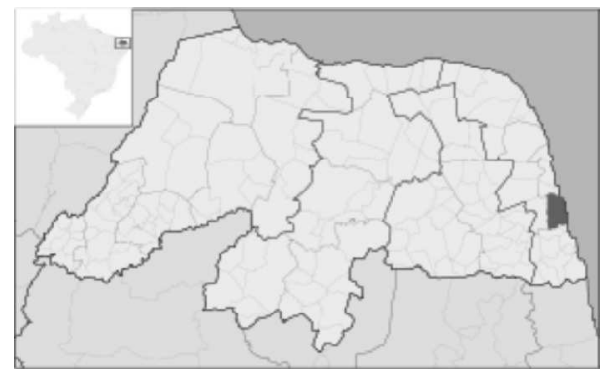

Fonte: IBGE, 2005. Município de Nísia Floresta em destaque

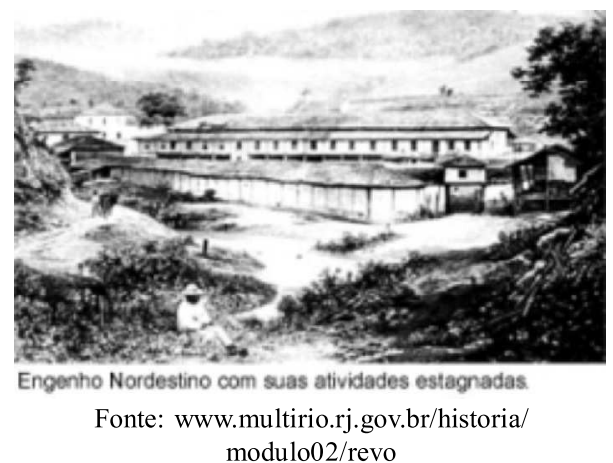

Nísia Floresta ou Dionísia Gonçalves Pinto, nome que consta do Assento de Batismo da Igreja de Nossa Senhora do Ó, nasceu em 12 de outubro de 1810 , no sítio Floresta, localizado no município de Vila de Papary. Filha do advogado português Dioniso Gonçalves Pinto, chegado ao Brasil no início do século XIX, e da brasileira Antônia Clara Freire, descendente de uma das principais famílias da região. A comarca de Papary, elevada à condição de cidade e sede municipal no ano de 1890 , dista $37 \mathrm{~km}$ de Natal, capital do estado do Rio Grande do Norte, região nordeste do Brasil, compreendendo uma área territorial de $306 \mathrm{~km}^{2}$.

A economia do povoado à época era parcamente impulsionada pela pesca e pela agricultura, determinando um atraso sociocultural gritante. A precariedade educacional se mostrava pela ausência de escolas. A instrução era oferecida a um número reduzido de crianças e exclusivamente pelas ordens religiosas instaladas na região. Aos meninos privilegiava-se o ensino da leitura, escrita e a realização das operações aritméticas básicas e às meninas, os trabalhos manuais. Embora o acesso à educação fosse limitado, a população não aceitava passiva os descasos de Portugal e a insatisfação se revelava nos movimentos revolucionários e nas agitações populares. As insurreições foram frequentes durante a estada da família real portuguesa no Brasil, entre os anos de 1808 - 1821, e o Segundo Império5. O destaque de alguns desses movimentos é importante por terem influenciado a vida de Nísia Floresta, como se verá adiante.

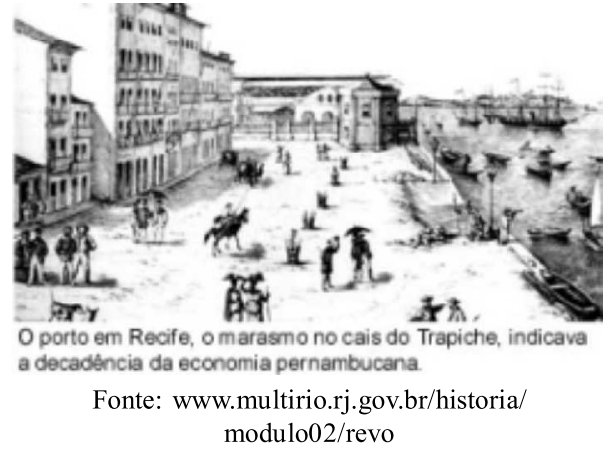

A Revolução Pernambucana ocorreu em 1817, como resultado da insatisfação dos habitantes da região nordeste que arcavam com o ônus de sustentar a Corte instalada no centro-sul do país, na cidade do Rio de Janeiro; e da política de favorecimento de D. João ao militares portugueses em detrimento dos brasileiros, que se viam em desvantagem diante das novas tropas trazidas de Portugal com a finalidade de fortificar as cidades fronteiriças do norte. Esses oficiais recebiam os melhores postos e o soldo era maior, fato que

\footnotetext{
5 FAUSTO, Boris. (1994): História concisa do Brasil, São Paulo, EDUSP, p 78.
} 
determinou aumento maior dos impostos, pois cabia à Colônia a manutenção das despesas e os gastos das campanhas.

O sentimento de contrariedade era forte na mais antiga área de colonização brasileira, especialmente por ter sido muito afetada pela crise das produções açucareira e algodoeira e pela seca de 1816. O desejo de independência da população era profundo e recorrente. Em Recife, capital da província de Pernambuco e um dos principais portos da região, o desagrado era intenso e havia uma compreensão generalizada de que os portugueses exploravam e oprimiam os pernambucanos.

Em 1821, iniciou-se um novo movimento emancipacionista, quando foi organizada a Junta Constitucionalista. Nessa época, era possível encontrar na região uma série de elementos ainda relacionados com a sublevação de 1817. As idéias liberais foram introduzidas no Brasil por viajantes estrangeiros, por livros e outras publicações que chegavam e incendiavam o sentimento de revolta. Em razão dos descontentamentos generalizados D. Pedro proclama a independência, em 1822, mas os movimentos insurgentes não cessaram. Destacaram-se a Confederação do Equador, a Cabanagem, a Balaiada, a Guerra dos Farrapos e a Sabinada.

A Confederação do Equador, proclamada em 2 de junho de 1824, contou com a participação de diversos segmentos sociais. $O$ caráter separatista do movimento pretendia negar a centralização e o autoritarismo que marcavam a organização política brasileira. As demais províncias do nordeste viviam situação semelhante. Cabanagem, nome dado ao movimento que ocorreu na província do Grão-Pará, entre 1835 e 1840, pode ser vista como um prosseguimento da Guerra da Independência na região e considerado o mais notável movimento popular do Brasil, por ter sido o único em que as camadas inferiores da população conseguiram ocupar o poder de toda uma província com certa estabilidade. A Independência não provocara mudanças na estrutura econômica nem modificara as péssimas condições em que vivia a maior parte da população da região. Dispersos pelo interior e nos arredores de Belém, encontravam-se marginalizados e em condições miseráveis, amontoados em cabanas à beira dos rios e igarapés e nas inúmeras ilhas do estuário do rio Amazonas. Essa população, conhecida como "cabanos," era usada como mão-de-obra em regime de semi-escravidão, pela economia regional.

A Província do Maranhão, entre 1838 e 1841, foi abalada por inúmeros levantes que receberam o nome geral de Balaiada, porque um dos seus líderes, Manuel Francisco dos Anjos, fabricante e vendedor de balaios, era conhecido pelo apelido de "Balaio". $\mathrm{Na}$ época, a população total maranhense contava aproximadamente com $200 \mathrm{mil}$ habitantes, dos quais 90 mil eram escravos. O reconhecimento da Independência, tanto no Maranhão quanto no Grão-Pará, não se fizera de modo pacífico; ao contrário, provocara conflitos entre colonos e portugueses, possibilitando que a massa de trabalhadores, formada pelas camadas mais pobres da sociedade, pegasse em armas por continuar marginalizada.

A Independência oficial sedimentou uma estrutura econômica e política herdada da Colônia, adotando um centralismo autoritário que pressionava o sistema político das províncias e pouco alterando a situação da população. A inviabilidade de 
democratização e a insistência na manutenção da escravidão fizeram aflorar todo o anacronismo do Estado brasileiro, provocando várias reações, especialmente no Rio Grande do Sul e na Bahia.

A Guerra dos Farrapos foi a mais duradoura, complexa, violenta e efetiva guerra de todas as que abalaram a Regência. Foi uma revolta econômica provocada pela centralização do poder imperial. Iniciou-se no dia 20 de setembro de 1835 e terminou em 28 de fevereiro de 1845. Alguns historiadores dividem a guerra em três fases: a primeira, de setembro de 1835 a setembro de 1836, a da separação; a segunda, de 1836 a 1843, fase de rebelião, e a fase de reintegração do Rio Grande do Sul.

A renúncia do Regente Feijó recrudesceu a insatisfação entre os militares e maçons da Província baiana, em 1837. O processo de instabilidade pelo qual passava a Bahia, culminou com o início da Sabinada, revolta liderada pelo médico Francisco Sabino Álvares da Rocha Vieira. Ao contrário de outros movimentos do Período Regencial, não mobilizou as camadas menos favorecidas nem conseguiu a adesão das elites provincianas, sobretudo dos grandes proprietários de escravos e de terras do Recôncavo. Por fim, em 1842, eclode a Revolução Liberal em São Paulo e Minas Gerais.

Todos esses movimentos influenciaram e forjaram, direta ou indiretamente, o caráter de uma das mulheres mais inteligentes e inovadoras do século XIX, como comprovam sua luta pela igualdade feminina, pela abolição da escravatura, pela liberdade de cultos, as denúncias contra o preconceito e contra o autoritarismo, e por seu trabalho como educadora.

\section{A História de Uma Brasileira}

Nísia Floresta foi uma mulher capaz de desmembrar-se em tantos quantos foram seus pseudônimos, não apenas como nomes simbólicos, mas também como nomes que representavam, denunciavam e lutavam contra as injustiças e, principalmente, pela educação à época do império e depois dele. Dionísia viveu sua primeira infância no sítio Floresta, extensa propriedade que, aparentemente, ocupava o território onde hoje se situam duas cidades. Os inúmeros movimentos revolucionários espalhados pelo nordeste foram os promotores de muitas das transferências de residência da família Gonçalves Pinto. A primeira delas ocorreu no ano de 1817, para a cidade de Goiana, importante centro cultural no interior do estado de Pernambuco, onde as jovens pertencentes a famílias prósperas iniciavam seus estudos. Após dois anos todos retornam a Floresta.

Como português, o pai de Dionísia foi por vezes perseguido porque os brasileiros se sentiam desprestigiados e desvalorizados diante dos lusitanos. Estas experiências deram a Dionísia os primeiros vislumbres dos ideais liberais e republicanos.

Aos treze anos de idade, em 1823, casa-se com Manuel Alexandre Seabra de Melo, dono de grande extensão de terras. O matrimônio terá a duração de apenas alguns meses; esse fato e o retorno à casa dos pais trarão muitos aborrecimentos à educadora, 
tanto pelo julgamento preconceituoso ao qual estará sujeita, quanto pela insistência do marido em fazê-la retornar ao lar do casal.

Novos conflitos obrigam Dionísio G. Pinto a se mudar com os parentes e desta vez a retirada de Floresta é definitiva. Transfere-se para Olinda, onde passa a exercer sua profissão, sobressaindo-se na defesa de causas que o punham contra os poderosos da cidade. Tal fato foi determinante contra sua vida e, na noite de 17 de agosto de 1828 , é assassinado no retorno para casa. Dentre os vários episódios significativos que auxiliaram a configuração da personalidade de Dionísia, este é um dos mais marcantes.

Ainda em 1828, enamora-se de Manuel Augusto de Faria Rocha

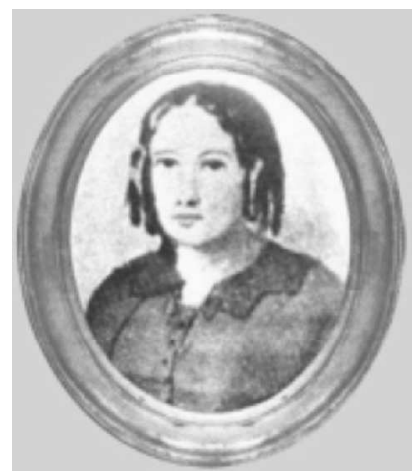

Nísia Floresta - estudante de direito da Academia de Olinda - com o qual passa a conviver maritalmente, desencadeando, no primeiro companheiro, reações ainda mais adversas e profundas. $\mathrm{O}$ nascimento de Lívia Augusta de Faria Rocha, em 12 de janeiro de 1830, sedimenta a relação. O encontro de Dionísia com as letras data de 1831, ainda no estado de Pernambuco, como colaboradora do jornal Espelho das Brasileiras, na produção de artigos que tratavam da condição da mulher nas culturas antigas. Nesse mesmo ano, nasce seu segundo filho, morto precocemente.

No ano de 1831, despontam a escritora e a educadora Nísia Floresta Brasileira Augusta, que lutará durante toda a existência contra as injustiças, as discriminações, os desmandos e as barbáries dirigidos aos menos favorecidos. O lançamento da tradução livre do livro Direitos das Mulheres e Injustiça dos Homens, de Mary Wollstoncraft, marca o início da trajetória literária. A escolha dessa obra não foi aleatória, pois nele se encontram questionamentos acerca da alegada incapacidade feminina para as ciências e a importância da educação, como se depreende de suas palavras:

Toda diferença, pois, vem da educação, do exercício e da impressão dos objetos externos, que nos cercam nas diversas circunstâncias da vida. [...] O pretexto que eles alegam é que o estudo e as ciências nos tornariam altivas e viciosas; mas este pretexto é tão desprezível e extravagante e bem digno do seu modo de obrar. ${ }^{6}$

Rio Grande do Norte e Rio Grande do Sul, curiosamente estados que se localizam nos extremos continentais do país, marcam aspectos de vida e de morte de Nísia. Porto Alegre será, em 1833, a nova morada do casal Nísia e Manuel, da filha e do filho Augusto Américo, nascido na primeira quinzena de janeiro. Após oito meses da mudança da família, repentinamente, morre Manuel Augusto no dia 29 de agosto. Nessa cidade, em que viverá por mais quatro anos com os filhos, a mãe e as irmãs, surgem as primeiras descrições formais da educadora e feminista, como diretora de colégio e defensora da emancipação da mulher.

6 AUGUSTA, Nísia Floresta Brasileira. (1989): Direito das mulheres e injustiça dos homens. São Paulo, Cortez, pp.47-49.

\begin{tabular}{l|l} 
Rhela. Vol. 13. Año 2009, pp. $11-27$ \\
\hline &
\end{tabular}


O movimento revolucionário gaúcho é responsável por nova transferência de cidade, agora para o Rio de Janeiro. Logo depois de se instalar, Nísia comunica à sociedade carioca pelo Jornal do Comércio de 31 de janeiro de 1838, a inauguração de seu estabelecimento de ensino nomeado Colégio Augusto. Em suas palavras:

D. Nísia Floresta Brasileira Augusta tem a honra de participar ao respeitável público que ela pretende abrir no dia 15 de fevereiro próximo, na rua Direita número 164, um colégio de educação para meninas, no qual, além de ler, escrever, contar, coser, bordar, marcar e tudo o mais que toca à educação doméstica de uma menina, ensinarse-á a gramática da língua nacional por um método fácil, o francês, o italiano, e os princípios mais gerais da geografia. Haverão igualmente neste colégio mestres de música e dança. Recebem-se alunas internas e externas. A diretora, que há quatro anos se emprega nesta ocupação, dispensa-se de entreter o respeitável público com promessas no desempenho dos seus deveres, aguardando ocasião em que possa praticamente mostrar aos pais de família que a honrarem com a sua confiança, pelos prontos progressos de suas filhas, que ela não é indigna da árdua tarefa que sobre si toma. $[\ldots]^{7}$

O texto de Nísia Floresta detalha com minúcias as atividades educacionais que seriam desenvolvidas no futuro Colégio. Esses argumentos talvez fossem necessários para o convencimento das famílias sobre a importância da educação das meninas. Competindo com escolas dirigidas por estrangeiros, propunha-se a alavancar o conhecimento oferecido às jovens. "A pedagogia nisiana partia do pressuposto de que a mulher merecia um ensino mais profundo, com o conhecimento de matérias até então reservadas aos homens, como o latim, por exemplo." 8

Considerado polêmico, o Colégio inovava ao introduzir o estudo de línguas vivas e conhecimentos gerais, pois até então, na grande maioria dos institutos de educação femininos, predominava a educação da agulha voltada para o ensino de prendas domésticas, noções rudimentares de matemática e o ensino superficial do português. $\mathrm{E}$ incentivar a prática de Educação Física, condenar o uso do espartilho e limitar o número de alunas por turma, como forma de garantir a qualidade do ensino. Nota-se neste item a preocupação e a visão precursora de Nísia.

O segundo livro da autora - Conselhos à minha filha -, presente a Lívia em seu $12^{\circ}$ aniversário, é publicado em 1842 . Em 1847, mais três publicações ocorrem: Daciz ou $A$ jovem Completa que dirigiu a alunas de suas escolas; Fany ou O Modelo das Donzelas, cujo conteúdo reunia as qualidades desejadas em uma jovem; Discurso que às suas educandas dirigiu Nísia Floresta Brasileira Augusta.

É significativa a relação de trabalhos em prosa e em verso produzidos por Nísia e publicados no Brasil e na Europa, mas, conforme seus biógrafos, são difíceis de serem

7 DUARTE, Constância Lima. (1991): Nísia Floresta: vida e obra. São Paulo, Tese de Doutorado, Universidade de São Paulo, FFLCH, p. 30.

8 Ibidem, p. 38. 
localizados, seja porque se perderam, porque a autora assinava por intermédio de pseudônimos ou porque simplesmente não os assinava.

Nísia empreende viagem para Europa, em 1849, com o intuito de cuidar da saúde da filha que sofrera um acidente, caindo do cavalo. Este fato, para muitos, serviu de pretexto para a ausência prolongada no exterior, dada à influência considerada desabonadora de uma educadora abolicionista, republicana e feminista, que pregava a independência da mulher. Era quase geral a opinião de "que a instrução intelectual era inútil, quando não prejudicial, às meninas." ${ }^{9}$ A estada na Europa serviu também para que Nísia aumentasse sua cultura e seu conhecimento. Ao entrar em contato com as teorias positivistas, inicia sua participação no curso de História Geral da Humanidade, ministrada por Augusto Comte.

No retorno ao Brasil em 1852, permite a publicação do Opúsculo Humanitário, no ano seguinte, livro que trata especialmente da educação feminina e condena os enganos cometidos nesta condução; desenvolve também conceitos e pensamentos doutrinários, reafirmando sua luta contra a discriminação. Na mesma esteira edita $A$ mulher (1857), denunciando a formação educacional dispensada às meninas.

Após dezessete anos de funcionamento, o Colégio Augusto é fechado, data que coincide com a nova partida de Nísia para Europa.

Em seu novo regresso ao Brasil, e passados muitos anos, alguns fatos importantes que fizeram parte de suas reivindicações aguardavam-na: a campanha abolicionista, o movimento republicano, o primeiro recenseamento. Contudo, estes não foram suficientes para mantê-la em território brasileiro. Depois de dois anos, parte definitivamente, fixando residência em Rouen, na França. Em 1878, publica seu último trabalho - Fragments d'um ouvrage inèdit: notes biographiques - dedicado à irmã Clara.

Em 24 de abril de 1885, idosa e doente, Nísia Floresta Brasileira Augusta morre acometida por uma pneumonia. Em 23 de dezembro de 1948, o município de Papari tem seu nome trocado por Nísia Floresta. O translado de seu corpo só ocorrerá em 1954.

\section{Os Sonhos Educacionais de uma Brasileira}

O panorama educacional brasileiro começa a sofrer modificações com a instalação da Corte Real no Brasil e passam a residir aqui professoras portuguesas e francesas que iniciam a escolarização das brasileiras abastadas. O ensino primário gratuito e para todos só será estabelecido após a Independência.

A educação das meninas sustentava-se na religião e na moral, valorizando o papel e a função de esposa e mãe, firmando a imagem de docilidade, fraqueza, meiguice e,

9 AUGUSTA, Nísia Floresta Brasileira. (1989): Op. Cit, p. 69.

Rhela. Vol. 12. Año 2009, pp. 11 - 27 
fundamentalmente, de dependente. As ciências eram vistas como inúteis às mulheres. Nísia considerava que,

Se cada homem, em particular, fosse obrigado a declarar o que sente a respeito de nosso sexo, encontraríamos todos de acordo em dizer que nós nascemos para seu uso, que não somos próprias senão para procriar e nutrir nossos filhos na infância, reger uma casa, servir, obedecer e aprazer aos nossos amos, isto é, a eles homens. ${ }^{10}$

Era consenso que o letramento proporcionaria à infầncia feminina entretenimento inadequado. Nísia Floresta acreditava, contudo, que a "virtude e a felicidade são tão indispensáveis na vida privada como na pública, e a ciência é um meio necessário para se alcançar uma e outra" "11, não sendo, apenas, os trabalhos domésticos e manuais as únicas ocupações aos quais as mulheres deveriam dedicar-se. Para a autora, a sustentação dessas práticas tinha o aval de educadores do cunho de J. J. Rousseau, que aconselhavam o gosto pelo adorno e o embelezamento do corpo para obterem a subjugação masculina. "Todos os que têm escrito sobre a educação da mulher, pregando tão errôneas doutrinas e considerando-a debaixo do ponto de vista puramente material, não têm feito mais do que tirar-lhe toda a dignidade de sua natureza" ${ }^{\prime 2}$. As seguidoras de tais proposições eram veementemente criticadas pela educadora, que as considerava mais entregues ao império dos sentidos do que ao da razão.

O propalado sexo frágil servia de justificativa para afastar as meninas do conhecimento. Discutindo e contrapondo-se a essa idéia, Nísia argumenta que o fato de a mulher apresentar um corpo menos robusto que o homem necessitava mais do intelecto para o cumprimento de suas funções maternas e matrimoniais.

No século XIX, individualidade e a mobilidade social apresentam-se como um dos marcos da sociedade ocidental; todavia, para a mulher, constituíam-se apenas em um princípio. A maternagem e o cuidado da casa davam contorno à educação e a lei as impedia de ascender aos cursos de ensino médio e superior, institucionalizados, aproximadamente em 1880. Para a educadora isso se configurava como "uma inveja baixa e indigna, que os induz [aos homens] a privar-nos das vantagens a que temos de um direito tão natural, como eles."13

Nísia tinha uma meta: formar e modificar consciências ${ }^{14}$. Os conteúdos de seus livros buscavam a alteração do quadro ideológico social, vigente à época das suas publicações, ao denunciarem o cenário da educação nacional e em sua militância procurava sedimentar e solidificar a práxis educativa.

${ }^{10}$ Ibidem, p. 35.

${ }^{11}$ Ibidem, p. 51.

12 FLORESTA, Nísia. (1989): Opúsculo Humanitário, São Paulo, Cortez, p. 61.

13 AUGUSTA, Nísia Floresta Brasileira. (1989): Direito das mulheres e injustiça dos homens,

São Paulo, Cortez, p. 49.

14 DUARTE, Constância Lima. (1991): Nísia Floresta: vida e obra São, Op. Cit, p. 38. 
A fundação do Colégio Augusto vem contemplar parte desse projeto. Dizia a autora:

As escolas primárias tinham antes o aspecto de casas penitenciárias do que de casas de educação. [...] A palmatória era o castigo menos afrontoso reservado às meninas por mulheres, em grande parte, grosseiras, que faziam uso das discipulas onde ousavam imprimir alguma vez a mão, sem nenhum respeito para com a decência nem o menor acatamento ao importante magistério que, sem compreender, exerciam. ${ }^{15}$

Em Opúsculo Humanitário é possível identificar a tese nisiana sobre o condicionamento do progresso social fincado na instrução e no conhecimento. Esse trabalho se detém, primeiramente, no lugar feminino ocupado na história da civilização para depois analisar e discutir o ensino brasileiro. Logo nos primeiros momentos do livro, a autora expressa sua insatisfação, dizendo:

Temos testemunhado pensadores das nações cultas em harmonizar a educação da mulher com o grandioso porvir que se prepara à humanidade. Nada, porém, ou quase nada temos visto fazer-se para remover os obstáculos que retardam os progressos da educação das nossas mulheres, a fim de que elas possam vencer as trevas que lhes obscurecem a inteligência, e conhecer as doçuras infinitas da vida intelectual, a que têm direito as mulheres de uma nação livre e civilizada. ${ }^{16}$

Nísia Floresta atribui a Portugal a situação educacional do Brasil no século XIX principalmente devido ao envio de uma classe de colonizadores que, conforme sua avaliação, em nada contribuía para o desenvolvimento nacional. Dizia: "Quanto mais ignorante o povo tanto mais fácil é a um governo absoluto exercer sobre ele o seu ilimitado poder." ${ }^{17}$ Entendia que os interesses eram prioritariamente econômicos.

A proclamação da Independência escancarou os descaminhos da educação, que exigiam uma profunda reforma do sistema e significativa mudança das mentalidades, em especial no que concerne à diferenciação entre instrução e educação, pois se constatava com facilidade que qualquer homem ou mulher que soubesse ler e escrever e tivesse meios de montar uma escola, julgava-se habilitado para intitular-se diretor de colégio. Nísia advertia:

Uma casa de educação entre nós é, em geral, uma especulação como qualquer outra. Calcula-se de antemão o número de alunos prometidos ou em perspectiva, as vantagens que podem resultar de uma rigorosa economia, em que por vezes a manutenção daqueles é comprometida. ${ }^{18}$

Respaldada pelos dados estatísticos oficiais promulgados pelo Quadro Demonstrativo do Estado da Instrução Primária e Secundária das Províncias do

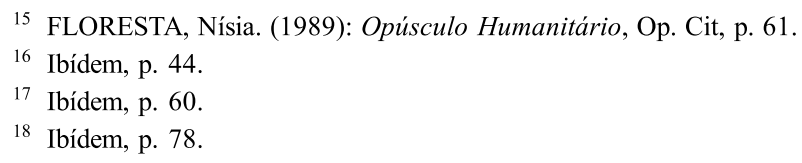


Império e do Município da Corte, em 1852, Nísia descortinou a realidade educativa brasileira ao mostrar o reduzido número de alunos freqüentando escolas públicas: 55.500 alunos, do quais apenas 8.443 eram do sexo feminino. A análise regional evidenciou um panorama mais sombrio, pois, nas províncias avançadas como Minas Gerais, Bahia e Rio de Janeiro, a porcentagem entre escolas dirigidas ao sexo masculino era, aproximadamente, $85 \%$ maior do que as dirigidas ao sexo feminino. Paulatinamente, mudanças ocorreram alterando o quadro geral.

O Opúsculo, além de revelar uma mulher interessante e avançada para sua época, expõe as influências às quais sua autora estava exposta e submetida. O pensamento liberal progressista e o pensamento positivista que norteavam sua orientação quanto à qualidade do ensino, a igualdade de gênero, o número de escolas, o acesso ao ensino secundário pelas meninas e as idéias higienistas se contrapõem a um exacerbado moralismo religioso, que impregnaram muitas das suas orientações e propostas, como é possível depreender de trechos como o que segue:

Entretanto, grande parte deste vê ainda sem repugnância seus filhos nos braços de desmoralizadas escravas ou, por elas acompanhadas, irem de uma a outra parte na habitação e fora dela. Quanta vez temos tido ocasião de ver e lamentar essas criaturazinhas, impregnadas já do hábito contagioso das más companhias, inutilizarem as proficuas lições de uma moral pura e fácil de seguir. Para essa desgraça muito concorrem às mães que se achando no caso de moralizar suas filhas, em vez de retê-las, como devem, junto a si, habituando-as aos bons costumes, instruindo-as com ações e palavras edificantes, folgam de poder desembaraçar-se do aborrecimento causado pelo choro ou motim das crianças, encarregando às pretas de acalentá-las ou distraí-las. ${ }^{19}$

Os trabalhos da autora, independentemente da influência ideológica, revelam sua preocupação com o desenvolvimento do brasileiro e a forte influência dos conhecimentos e das práticas educativas e escolares européias.

Duarte, analisando o mesmo livro, mostra que a autora, apesar de precursora, pouco avançou no que se refere às possíveis mudanças nas condições de vida de suas contemporâneas, pois, ao evocar uma formação cultural feminina aprimorada, suas sugestões enclausuravam a mulher nas mesmas funções cotidianas, ou seja, o cuidado com a casa e a família, sem a chance de satisfação ou prazer em outra atividade que não a maternidade. O feminismo de "Nísia Floresta parece se encaixar mais no "bom feminismo', pois não pretendia alterar substancialmente as relações sociais e conservava as mulheres nos limites ideológicos do privado" ${ }^{20}$. E, estudando Conselhos à minha filha, transcreve uma passagem que confirma a exaltação dada por Nísia à figura materna e o enaltecimento do título de "mãe":

Se há no mundo um título que enobreça a mulher, é sem dúvida o de mãe; é ele que lhe dá uma verdadeira importância na sociedade. Feliz aquela que o sabe dignamente

19 Ibídem, p. 96.

${ }^{20}$ DUARTE, Constância Lima. (1991): Nisia Floresta: vida e obra, Op. Cit, p. 335. 
preencher sentindo toda a sua grandeza, todas as suas obrigações! doces obrigações, cujo exercício tanto ameniza o fragoso caminho da vida e faz suportável o peso seu à triste, que a desgraça oprime. ${ }^{21}$

Sugerimos, entretanto, que as razões que a levaram a tais recomendações ultrapassam as questões religiosas e moralizantes. Evidenciam a observação apurada de alguns comportamentos da população: ausência do cuidado materno, ociosidade, indolência e escravidão. Assim, se os estudos não figuravam como emancipadores ou prazerosos, apresentavam-se de grande importância na educação dos filhos e na garantia e manutenção da família, visando ao desenvolvimento e crescimento do povo. As orientações dadas às jovens vinculam se adequadamente a esse modo de ser, mesmo que as sugestões apresentem um cunho paternalista aos moldes do comportamento cristão.

Nísia acreditava que as jovens não valorizavam o cuidado da criança, delegando essa tarefa às escravas que viciavam os comportamentos e as atitudes infantis. Por ser abolicionista, essa preocupação apresenta-se deslocada das suas pregações, mas o seu sentido está na via do cativeiro e na educação do chicote a que estavam submetidos os negros, implicando o colonizador, o senhor de escravos e o comerciante como responsáveis pela degradação social. Acreditando que nenhuma instrução conseguiria apagar as marcas desse convívio, visto que fazia parte do cotidiano e era repassada tradicional e ininterruptamente, insistia na discrição para a formação e os afazeres femininos. Dizia em o Opúsculo:

Enquanto o governo e os pais não reconhecerem o dano de tais práticas e se esforçarem por bani-las inteiramente, em vão uma ou outra voz se levantará para indicar os meios de um melhoramento, considerado ainda por muita como utopia. (...), mas, se na insuficiência de enérgicas medidas do governo para a reforma da nossa educação, apelamos para os pais de família, é porque estamos convencidos de que, em um país onde a escravidão é permitida, deles dependem principalmente os meios de subtraírem seus filhos a grande parte dos inconvenientes que os prejudicam..$^{22}$

A ociosidade e a indolência dos filhos da burguesia, vistas como marca edificante e notória das condições socioeconômicas familiares, determinaram, segundo sua análise, o futuro e a identidade da sociedade nacional, observando que em geral os brasileiros não conhecem a economia do tempo e é bem para lamentar que as classes pobres, principalmente, não se compenetrem da necessidade dessa economia e das vantagens que resultariam a seus filhos, se lhes apresentassem sempre com nobreza a imagem do trabalho, que devia caracterizá-las e distingui-las na sociedade de seu país.

Se o desprezo do trabalho produz nas classes abastadas funestas conseqüências, o que será das pobres, máxime daquelas que, não se resignando com o estado em que "Deus as colocou, querem mostrar-se aos olhos do mundo trajados acima da sua condição" ${ }^{23}$

${ }^{21}$ Ibídem, p. 341.

22 Ibídem, p. 109.

23 Ibídem, p. 127.

Rhela. Vol. 12. Año 2009, pp. $11-27$ 
O trabalho, tanto intelectual quanto material, foi destacado, então, como aspecto educativo primordial. Esse alerta fundava-se também na observação de meninas que, inspiradas mais na futilidade do que nos conhecimentos, apresentavam exacerbada fraqueza de caráter, demonstrada quando contrariadas ou desobedecidas, fazendo-as crer que pertenciam a uma "raça privilegiada, superior a todos os seus semelhantes sujeitos às eventualidades da fortuna." ${ }^{24}$ Nísia indicava a execução de trabalhos que fossem úteis e agradáveis, com a finalidade de forjar uma mulher virtuosa e sábia, pronta para os compromissos de mãe, de educadora, de esposa e companheira. Afirma em o Opúsculo: "Quereis ver a mãe na sublime simplicidade do amor materno? Contemplai as indígenas em todas as correrias que eram e são forçadas a fazer, seguindo os maridos através dos bosques, perseguido ou fugindo ao inimigo, sobrecarregadas dos filhinhos, além dos objetos que são obrigadas a levar." ${ }^{25}$

Nísia queria a criança como criança. Surpreendia-se ao comparar as meninas européias com as brasileiras; umas, "exprimindo com mais ou menos espírito, porém sempre naturalmente, a ingenuidade de sua alma refletida em sua fisionomia infantil" ${ }^{26}$; outras, "pequenas criaturas apertadas nas barbatanas de um espartilho, penteadas e vestidas à guisa de mulher, afetando-lhe os meneios e o tom, destituídas muita vez de toda a simpleza e candura que constituem o maior atrativo da infância." ${ }^{27}$

Calcada em sua práxis educativa e atenta ao desenvolvimento infantil, a autora apontava para um modo de ser da infância necessária ao pleno crescimento. Insistia nas mudanças da educação brasileira, que negligenciava a apreensão suficiente e adequada do conhecimento, embutia uma exposição velada da figura feminina sob a capa da sensibilidade das jovens e dividia os brasileiros em duas classes distintas: rica e pobre.

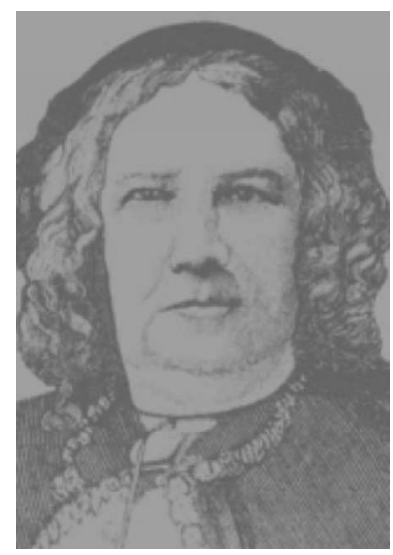

Invitava, em suas postulações, que se contemplasse a classe menos favorecida com uma educação melhorada, colaborando para o afastamento da miséria, dada a escassez de seus recursos e "porquanto o seu abandono a expõe aos mais tristes extremos, não possuindo o prestígio de um título nem as galas da riqueza, que disfarçam e fazem mesmo desculpar os vícios abrigados nos salões." ${ }^{28}$ Essa análise poderia ser compreendida como expressão da vivência dos períodos de acentuada convulsão social que a autora experimentou na infância e adolescência. Nísia Floresta encerra o Opúsculo Humanitário incitando: "Educai [para isto] a mulher e com ela marchai avante, na imensa via do progresso, à glória que leva o renome dos povos à mais remota posteridade" 29

\footnotetext{
${ }^{24}$ Ibídem, p. 119.

25 Ibídem, p. 149.

26 Ibídem, p. 105

${ }^{27}$ Ibídem, p. 105

28 Ibídem, p. 131.

${ }^{29}$ Ibídem, p. 160.
} 


\section{CONSIDERAÇÕES FINAIS}

A vida e obra de Nísia Floresta se entrelaçam como força de conhecimento, dialogando com a objetividade presente em suas proposições e a subjetividade de suas contradições; suas obras revelam uma mulher erudita, surpreendentemente crítica e paradigmática; sua erudição a lança no futuro, vislumbrando a emancipação feminina e o afrontamento da hegemonia masculina; sua verve crítica lhe permitiu analisar o mundo, não como algo dado, mas como um lugar de desvelamentos; analisar a educação brasileira e indignar-se com ela; ver o lugar social ocupado pela mulher e escrever sobre como seria possível transformá-lo. Entretanto, erudição e criticidade não impediram que as contradições de suas postulações se fizessem presentes, levando-a a transitar entre o conservadorismo e o vanguardismo.

O conservadorismo, em especial o religioso, impunha-lhe, aparentemente, uma destinação feminina pouco distante da apregoada e mantida até então: o controle da mulher e o amor que deveria devotar ao marido e aos filhos. Em vários momentos de sua obra, são oferecidas sugestões e indicações precisas de como manter o lar e a família em harmonia, demonstrando a influência feminina "sobre a moralidade e a civilização dos povos". Contudo, para ela, a relevância do papel e da função da mulher não se restringia ao cuidado da casa e dos filhos. E aí está o vanguardismo nisiano escancarando o devir. A mulher executa hoje as mesmas atividades que suas antepassadas, mas o acesso à escola, ao conhecimento, ao mundo fora do lar proporcionou sua emancipação. Nísia Floresta insistia nisso, acreditando que a libertação só ocorre quando o sujeito está livre da subjugação.

O conjunto de conhecimentos transmitidos configura o indivíduo, delineia sua identidade e produz um tipo específico de pessoa. A experiência adquirida numa mesma dimensão sócio-histórica predispõe as pessoas a comportamentos e atitudes semelhantes, mas não impede que uma metamorfose ocorra e subverta a ordem social, transformando o estabelecido pela via do conhecimento, como mostra Nísia Floresta Brasileira Augusta, uma mulher adiante das imposições de seu tempo histórico.

\section{FUENTES}

BRASILEIRA AUGUST, Nísia Floresta. (1832): Os Direitos das mulheres e injustiça dos homens, por Mistriss Godwin. Tradução livre do francês, Recife. Typographia, Fidedigma.

. (1842): Conselhos à minha filha, Rio de Janeiro, Typographia de J. E. S.

Cabral.

. (1847): Fany ou o Modelo das donzelas, Rio de Janeiro, Colégio Augusto.

(1847): Daciz ou a Jovem completa. Historieta oferecida as suas educandas, Rio de Janeiro, Typographia de F.

Rhela. Vol. 12. Año 2009, pp. $11-27$ 
(1847): Discurso que às suas educandas dirigiu Nísia Floresta, em 18 de dezembro de 1847, Rio de Janeiro, Tpographia Imparcial de F.

. (1849): A lágrima de um Caeté, por Tellesila, Rio de Janeiro, Typographia de L. A. F. Menezes.

. (1850): Dedicação de uma amiga, (Romance Histórico). Por B. A. 2 volumes. Niterói: Typographia Fluminense de Lopes \& Cia.

(1853): Opúsculo Humanitário, Por B. A. Rio de Janeiro, Typographia de M. A. da Silva Lima.

. (1854): Páginas de uma vida obscura; Um passeio ao aqueduto da Carioca; O pranto filial. Rio de Janeiro. Typographia de N. Lobo Vianna.

.Intineraire d'un voyage en Allemagne. Par Mme. Floresta A. Brasileira. Paris: Firmin Diderot Frères et Cie. Bianchi \& C.

(1859): Scintille d'un'Anima Brasiliana, Firenze: Tipografia Barbera, Impr, du Monnier.

. (1859): Conseils a ma fille, traduit de l'Italien par B. D. B, Florence, (1860): Le lagrime d'un Caeté, Tradotto da Ettore Marcucci, Firenze, Le Monnier.

(1864): Trois ans en Italie, Suivis d'un voyage en Grèce. Par Une Brésiliènne. Paris, Libraire E. Dentu.

(1867): Woman. By F. Brasileira Augusta. Translated from the Italian, by Livia A. de Faria. London: Printed by G. Parker, Little St. Andrew Street, Upper. St. Martin's Lane.

\section{Sagnier.}

. (1871): Le Brésil. Par Mme. Brasileira Augusta. Paris: Libraire André Chérié, Editeur.

. (1878): Fragments d'un ouvrage inédit: Notes biographiques. Paris: A.

\section{SELECCIÓN BIBLIOGRÁFICA}

AUGUSTA, Nísia Floresta Brasileira. (1989): Direito das mulheres e injustiça dos homens. São Paulo, Cortez.

BENJAMIN, Walter. (1983): O narrador: Observações sobre a obra de Nikolai Leskow, in Coleção: Os Pensadores. Textos escolhidos, Benjamin, São Paulo Horkheimer, Adorno, Habermas. 
DUARTE, Constância Lima. (1991): Nísia Floresta: vida e obra, São Paulo, Tese de Doutorado, Universidade de São Paulo, FFLCH.

Cultural.

. (2006): Nísia Floresta: uma mulher à frente do seu tempo. Brasília: Mercado

FAUSTO, Boris. (1994): História concisa do Brasil, São Paulo, EDUSP.

FLORESTA, Nísia. (1989): Opúsculo Humanitário, São Paulo, Cortez.

FLORESTA, Nísia. (1998): Itinerário de uma viagem à Alemanha. Santa Cruz do Sul: Mulheres.

FLORESTA, Nísia. (2001): Fragmentos de uma obra inédita. Notas biográficas. Brasília, Universidade de Brasília.

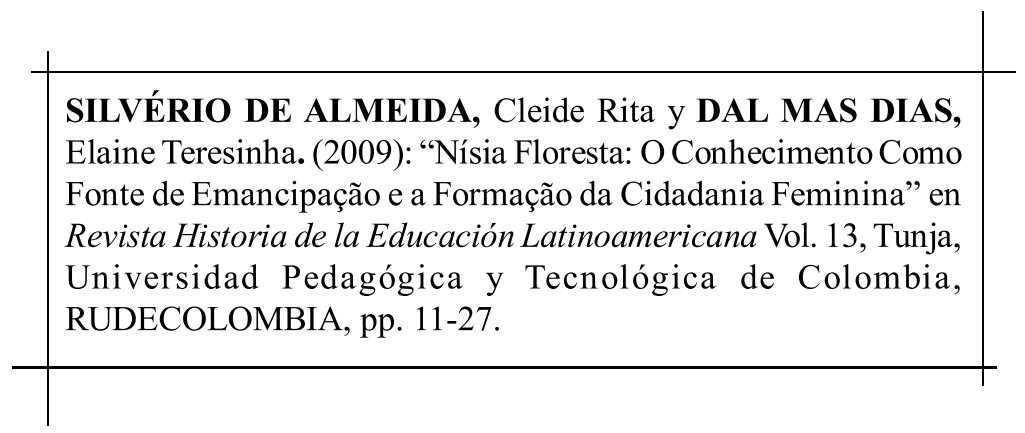

Rhela. Vol. 12. Año 2009, pp. $11-27$ 